Варто зазначити і про умови вступу на факультет англійської мови, які є досить високими, адже прийом на факультет здійснюється виключно на основі академічної успішності, включаючи мінімальний рівень за екзамен 3 англійської мови - «5» в Гонконзькому дипломі про середню освіту (HKDSE), або оцінку «С» за екзамен на рівень знання англійської мови - Use of English AS-level exam, чи його еквіваленти.

Перспективи подальших наукових досліджень можуть бути пов'язані 3 вивченням змісту дисципліни «Англійська мова» для освітньо-кваліфікаційного рівня «Магістр» в університетах КНР та дослідження питання проведення педагогічної практики.

\title{
Література
}

1. Англійська мова та іiі важливість на сьогоднішній день. [Електронний pecypc].- Режим доступу: http:/www.movi.com.ua/angliyska-mova/813-angliyskamova-i-yiyi-vaglivist 2. Regulations and syllabuses (BA 3-year curriculum in the academic year 2013-2014) [Електронний ресурс] - Режим доступу: http://arts.hku.hk/ BAprogramme/2010/advising/BA \%20 RegulationsSyllabuses \%202013-14.pdf. 3. Xie Bangxiu. English in China Today (Wuhan, China) [Електронний ресурс]/ Bangxiu Xie.- Режим доступу: http://www.jesusjazzbuddhism.org/ english-in-chinatoday.html

\section{ACCORDION TRAINING IN MUSIC SCHOOLS IN SERB ACADEMICALLY POPULAR TYPE}

Устименко-Косоріч О. А. Професійна підготовка баяністів-акордеоністів в сербських музичних школах академічно-народного типу. У статті проаналізовано професійна підготовка баяністів-акордеоністів сербської школи академічно-народного типу за двома освітніми напрямами професіонал/аматор, які презентують прогресивну освітню систему, що реалізовує двоєдину біфункціональну програму - виховання компетентного фахівця суспільно-національного призначення (аматора) та потенційного виконавця «Високого мистецтва» засобами «узагальнення через жанр».

Ключові слова: професіонал, аматор, музична школа, баян-акордеон, підготовка, нація, суспільство, виконавство.

Устименко-Косорич Е. А. Профессиональная подготовка баянистоваккордеонистов в сербских музыкальных школах академически-народного типа.

В статье анализируется профессиональная подготовка баянистов-аккордеонистов сербской школы академически-народного типа по двум образовательным направлениям - профессионал / любитель, которые представляют прогрессивную образовательную систему, реализующая двуединую бифункциональных программу воспитание компетентного специалиста общественно-национального назначения (любителя) и потенциального исполнителя «Высокого искусства» средствами «обобщение через жанр».

Ключевые слова: профессионал, любитель, музыкальная школа, баян-аккордеон, подготовка, нация, общество, исполнительство.

Ustymenko-Kosorich O. A. Accordion training in music schools in Serb academically popular type.

The article analyzes the training of accordion Serbian school of academically popular 
type of two educational areas - professional/ amateur, which represent progressive educational system that implements a dual bi-functional program - education of a competent specialist of national public purpose (amateur) and a potential artist of «high art» «means a compilation of genre».

Key words: professional, amateur, music school, accordion, training, nation, society, performing.

Modern educational profile of Serbian button accordion and accordion school of academic and popular types enables to note two conceptual educational positions: first - the training of competent amateurs who have two inseparable functions: consumption of music as a competent and educated professional, amateur music-performing as a kind of musical and professional activity, the second - education of future specialists of elite class, who are able to master the complex of techniques of «universal status» performance in a professional manner and present button accordion and accordion school in the world.

Clarification of these issues makes it possible to establish a connection between educational, amateur and professional activities on an example of academic and popular types of Serbian button accordion and accordion schools and implement an educational and musical project in the national training system of accordionists and button accordion players, which to this day remains a highly specialized training base of a musical instrument playing, which is of particular relevance within our study.

Analysis of musical, pedagogical and historical literature allowed to state that the study of the characteristics of the development and functioning of the Serbian accordion and button accordion school appealed to a number of researchers. The authors disclose its historical and cultural profile, basic musical education and pedagogical tenets. Among them: Z.-M Vasilyevich, B. Yovanchich, T. Bohavats, S. Dzhurich-Kline, P. Maystorovich, K. Manoylovich. The study of scientific literature enables complete factual data, identify musical and pedagogical trends in the making Serbian button accordion and accordion school of academic and popular type due to new scientific and theoretical developments.

The purpose of the article - identify educational principles of training of accordion and button accordion players in schools of academic and popular types.

A good implementation of two opposition tasks raises many issues that ultimately are not clarified: what skills should have a graduate accordionist of middle level music school and a musician - a specialist of an academic direction, what educational technology is in the process of folk and professional training, which personal qualities must possess a button accordionist of academic or popular direction, how training requirements are reflected in the programs of button accordion and accordion schools and methods of training of different direction?

We should take into consideration that most graduates of Serbian button accordion and accordion school of academic and popular types, which focuse their interest on unprofessional determined musical creativity become active amateur musicians. Minority of students of button accordion and accordion schools get the opportunity not only to continue their studies in a higher education institution, but in the future become skilled musicians performers, conductors, teachers, heads of musical ensembles, orchestras, ensemble managers in culture, music critics.

It is difficult to overestimate the importance of the quality of training for the entire future of the professional musician since those specialty and specialization are rooted in the music school. P. Antokhin notes that in conditions of unilateral training of a musician, artistic essence of musical activities and development performer loses meaning. [1, s. 18]. Consequently, the quality of training in primary and secondary music school depends on the 
professional level of students in higher education music institutions, in wider meaning competence of musical training in the country.

The question is exactly how in one musical institution nurture a competent performer of extra quality and a specialist of a general profile? To answer this question, we will analyze the creative activity of graduates of Serbian button accordion and accordion schools on the level of knowledge and skills of musicians for whom music is a «spiritual impulse», a hobby.

Graduates of button accordion and accordion schools should be qualified as «amateurs», who can conditionally be divided into two categories: consumers of musical production, which are limited to visual auditory approach to their own musical activity in the form of visits of concerts, plays, listening to audio recordings of good quality music, amateur accordionists who take part in performing activities - participants of collective forms of music (folk orchestra), accompanist to other amateurs (singers, instrumentalists) and singers soloists.

E. Nazaykinskyy notes that the functions and features of musical and auditory qualities depend on the type of music to which the author refers musical thinking of a composer, a performer and a listener. According to the researcher, the listener provides an artistic communication link between the author of the work and the artist, when musical perception serves the purposes of artistic, spiritual and aesthetic impact of music on the listener . And in this sense, emphasize a centralized value audience of listeners perception of music for all kinds of musical activities, including amateur listener that requires the development of appropriate musical education system within the button accordion and accordion school.

Amateur musicians of the first group are characterized by a deep need for systematic visual auditory act - the perception of music, aesthetic pleasure as a source of spiritual energy. E. Kurt notes that musical and artistic content of music holds life and fantasy images that requires the listener 's metamorphic speed and other personal qualities to some extent, emotional and intellectual development of aesthetic education [7, s. 4]. Note that amateurs of «active category» inherent resistant auditory activity generated music consumption. For its proper functioning a musicial consumer should have: the ability of adequate perception of music, playing in its own interpretation of its artistic content; emotional and figurative sense of music, being able to analyze the aesthetic quality of music and professional level of performance thanks to advanced intonation hearing, thinking, presentation; perfect awareness and musical panorama of different eras, styles and genres, the idea of the traditional music of other nations, outstanding works of composers of the past and present; knowledge in the field of musical form and content of certain works; skills in analyzing specific performance of music by various artists and creative teams; orientation to the constant increase of its fund by ancient, classic, romantic and modern music performing various schools and trends; show some interest in the music world events: the creation of new music, new artists, composers, top performing competitions and concerts.

Music amateurs who posess a set of these skills can be attributed to the category of competent listeners, so the concept of «a competent amateur music listener» can be put on a musical science - sociology of music, music pedagogy, music theory education. D. Kyrnanska musical perception considers the position of psychology and musical science and points to a comprehensive quality of this phenomenon, which brings together those aspects of music that are considered separately in musical science (structure, genre, tone, etc.) in the mental image, «the nature of which varies depending on the characteristics of perceiving consciousness» [6, s. 8].

We emphasize that the relationship of music and culture, on the one hand and the competent listener on the other, has a two sided meaning: musical compositions affect the level of individual perception and cause a wide range of appropriate emotions, but also educated listener that adequately assesses the musical production and has musical taste, audience of 
listeners experience as a feedback brings its own share in the development of musical culture. And in this sense, amateur listeners believe it would be an active category of musicians who realize their own spiritual and aesthetic needs in the «communion of musical art» [4, s. 14].

It becomes clear that the highly specialized training to play the instrument, mastering a limited repertoire of music school is unable to provide quality knowledge and skills, laying the foundations of musical culture that are needed to adequately competent listener perception of music. It is known that the specified range of skills required and amateur artist, but for quality amateur music performer must additionally have: the ability to perceive and understand the tonal language of music and artistic and imaginative content of musical works performed; high level of musical thinking (inner ear and sense of intonation temporythm); resistant qualities of remembering that rely on auditory (sound) components; developed playing machanism and a certain level of instrumental technique, skills of sound building, performing means of musical expression; skills of orchestral music, understanding the role of conductor in collective forms of musical activity; awareness of the nature of collective creativity and its role in the collective creative process; certain skills in musical notation, the technique of reading notes sheet; ability for improvisation; developed texture-performing hearing.

It becomes clear that music and performance requirements for the amateur musician are considerably higher than the amateur listener, which essentially are close to professional ones. We can assume that the foundation of musical skills of a musician should be fundamentally similar for both the amateur and for a professional musician. Therefore, qualifying the distribution of students in the Serbian button accordion and accordion school happens after three years of study.

To justify the extended position, we should analyze the complex of personal qualities analysis, skills and knowledge of secondary music school, a potential professional artist, who aims to increase his skills level in high school.

The main special quality of performing musicians is advanced hearing, in other words «adequate perception» by V. Medushevskyi [8, s. 142], who believe it would be a complex system, which integrates intonation and analytical components. Note that a musician of any orientation should have a developed ear for music as a condition for the development of musical thought, but in the latter case, an ear for music is considered in the context of anticipation - the ability of prediction (proactiveness). Performing actions on «virtual sound» model that adjusts and controls practical action performer. Advanced intonational pitch allows musicians to represent execute the instrument and simulate the structure of music - from simple intonation and genre forms to complex theories of music. Analytical ear adjusts real time according to the «virtual» model (easy shaped, structural logic, individual interpretation of projection piece of music performer).

Thus, within the auditory «adequate perception,» which is broadcast audio material (language and intonation) nature music, actualized «individual artistic image». Adequate perception is sound and musical ideal perception of musical composition is based on personal pan cultural experience. In a music school development of musical perception in musicians distinguish the category of the most important tasks that examine the phenomenon of musical culture.

A fundamental role in the musician's activity plays a heightened sense of rhythm, which is placed at the initial development stage of a performer and brought to the level of «a future metro-rhythmic culture» in the unity of all its components - from the metrical pulse, feeling the size, pace and placement accentuation to ahogynic deviations and correlation parts of compositional forms in accordance with logical proportions. Theory of musical pedagogy is based on the position that says that the foundations of music and rhythmic organization musician contained in the internal sense of metrical regularity and uniform pulsation, 
organically connected with the functioning of the whole human organism» $[4, \mathrm{~s} .12]$. By E. Jacques-Dalcroze, «an original system of rhythmic education an artist becomes effective in the development of musical thinking, memory and other qualities of the musician» [5, s. 453].

A professional artist must possess skills which are adequate to perception and understanding of music and intonation of speech on the basis of his or her figurative and artistic content of music, introduce an interpretation performing style in accordance with the aesthetic tendencies and personal musical experience. A potential performer develops a set of personal qualities that are at different stages of performing experience providing successful musical creativity. In particular, artistic skills, who are brought up in the student in the understanding of the socio-cultural significance of music and «ongoing dialogue» with the audience; commitment to profession that justifies the emotional burden of performing energy of artistic act (recitals, creative and collective activity), stressful situations in the artistic act and the role of concentration to keep the mind and body stability.

Career Executive determines the perfect development of specialized memory, which relies on a set of elements: imagery, auditory, motor, tactile, metro-rhythmic, logical, linguistic, emotional, harmonious, textured, positional, who works in the active memory, money saving and efficiency broadcast music.

These professional profile as a specialist musician lays within the School of Music in sequence in the accumulation of musical repertoire, who since joining the student to university is large list of music that covers a variety of styles, genres, historical periods of national and foreign origin. In this sense, the main feature of a performer is the development of reading notes from the letter, which translates into a professional level performer - by $\mathrm{M}$. Aranovskiy, «playing music at sight» [2, s. 253].

The problem of learning musical repertoire, mainly in the national primary music schools enables proposal on the shift from sequential study criteria complexity limited number of musical works and their single reporting performance (academic concert, technical test, exam) on the progressive development of database performance culture based on the number of student works available in a multiple of their presentation on stage. In Serbian bayan accordion school academic and popular type of such material has become folk music that can be considered as «music of a particular society, nation.» Social demand for music products of popular genre allows to educate in potential artists artistic qualities on the basis of regular concert events at affordable music and traditional materials, which is a universal base for potential perpetrators of academic level and for a future amateur.

In the national music school musical material may be pop folk music that contains artistic sense and technical performing complexity. The authors of such works can become teachers of button accordion, professional composers and students themselves, the task of the teacher is to bring music to the appropriate level, namely to contribute to the creative work of his or her student. Compliance with program requirements teachers, containing a list of works for each year of the study, accordionist and its interpretation by experts as a base, not as additional (proposed) cancel creative sense of education, namely inhibits general musical personality development, incentive to continue improving performance skills . Performance of music education at all levels, in our opinion, depends primarily on the activity of primary school, which lays the foundation for complex musical qualities of youth, raising awareness and commitment to the future of the profession, interests certain type of music, it is «momentum» for further professional development of the individual.

Accumulation of repertory background is particularly effective when the process of working on repertoire acquires systematic approach. That mastery repertoire focused on the following objectives: deciphering musical text; intonation analysis of thematism and means of musical expression, determine artistic and imaginative content with detailed analysis of 
the technical difficulties, the projection of musical material as a coherent artistic and meaningful work, training of performing, stage of readiness; concert and public appearance.

Practical development of basic professional skills profile of an accordionist is made possible by effective playing system that provides, according to L. Archazhnykova, implementing elements of instrumental performance technology of virtuoso plan [3, s. 12]. Thus, the technical ability of the musician not to be just a technical motor characteristics or textured elements, we mean the widespread use of the bayan-accordion instrumental capabilities - tone, means of musical expression, techniques of sound building and others.

By the end of elementary school music a button accordionist or an accordionist has skilled collective music, accompaniment, understanding of manual technique conductor. Professional interests potential perpetrators can not be focused only on their own professional and educational activities. The objective of music school is much broader - to provide information about significant events in the music industry and other arts, adapt to the process of listening to music education major performing schools, outstanding musicians, attend organized concerts, cultural and public institutions, nurture intellectual and creative potential specialist of accordion skills.

We emphasize that stimulation of professional and executive activity occurs at an early stage of learning. Personal opinion gives grounds to consider pre-professional training key link in the procedural system of the whole complex of music education (music school + college + university ), which explains the design and logic of the development of our educational model that focuses on the initial stage of education of button accordionists, an accordionist on a scale of a specialist / amateur for example Serbian bayan accordion school of academic and popular type.

Let's note that the educational model of a specialist / amateur is little different from preparation techniques, as has shared a complex of personal, motivational, practical and professional components: commitment to the profession, permanent need in the perception of music; deepening awareness and musical panorama performing schools; understanding of genre and style differences and so on.

Prospects of further scientific studies to see further study of button accordion and accordion school of academic folk type ratings in the context of professional actors, artists and educators.

\section{Literature}

1. Антохин П. К. Функциональная система - основа физиологической архитектуры поведенческого акта / П. К. Антохин // Системные механизмы высшей нервной деятельности : избр. тр. - М. : Наука, 1979. - С. 3-80. 2. Арановский М. Г. Мышление, язык, семантика / М.Г. Арановский // Проблемы музыкального мышления : сб. ст. / под ред. М. Г. Арановского. - М. : Музыка, 1974. - С. 90 - 128. 3. Арчажникова Л. Г. Профессия - учитель музыки / Л. Г. Арчажникова. - М. : Просвещение, 1984. - 112 с. 4. Барбузюк Т О. Развитие отечественного начального музыкального образования как проблема музыкознания : дис. ... канд. искусствоведения : 17.00.02 / Барбузюк Татьяна Олеговна. - Магнитогорск, 2008. 246 с. 5. Жак-Далькроз Э. Ритм / Э. Жак-Далькроз. - М. : Классика-XXI, 2001. 248 с. 6. Кирнарская Д. К. Музыкальные способности : учеб. пособие для студ. высших учеб. заведений / Д. К. Кирнарская. - М. : Таланты - XXI век, 2004. - 496 с. 7. Курт Э. Романтическая гармония и ее кризис в «Тристане» Вагнера / Э. Курт. - М. : Музыка, 1975. - 550 с. 8. Медушевский В. В. О содержании понятия «адекватное восприятие»/ В. В. Медушевский// Восприятие музыки : сб. ст./ ред.-сост. В. Н. Максимов. - М. : Музыка, 1980. - С. 141-145. 